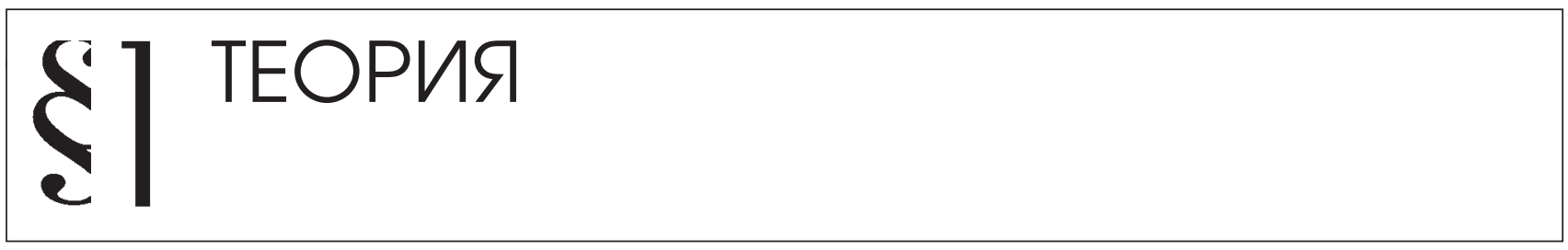

Кабанов П.А.

\title{
РОССИЙСКАЯ ПОЛИТИЧЕСКАЯ КРИМИНОЛОГИЯ: СПОРНЫЕ ВОПРОСЫ И НЕОДНОЗНАЧНЫЕ ОТВЕТЫ
}

\begin{abstract}
Аннотация: в статье рассматриваются теоретические вопросы статуса современной российской политической криминологии как самостоятельной отрасли криминологических знаний. Автором дается краткий обзор состояния исследований этого направления гуманитарных знаний в России и за рубежсо. Обосновывается авторское видение предметного поля российской политической криминологии, описываются спорные теоретические проблемы и предлагаются механизмы их разрешения в ближайшей перспективе. Отдельно автором формируются основные задачи, на решение которых необходимо сосредоточится современным российским политическим криминологам.

Ключевые слова: Юриспрудениия, политическая преступность, политическая криминология, зарубежная политическая криминология, политический преступник, криминальная конспирология, криминальная антропология, криминальная политическая этиология, политический терроризм, электоральная криминология
\end{abstract}

ачало XXI века большинством отечественных и зарубежных криминологов характеризуется интенсивным ростом преступности и её глобализацией, что, безусловно, требует адекватных ответов со стороны мирового сообщества. В этих условиях становиться важным криминологический анализ состояния преступности в мире, закономерностей её развития и разработка эффективных мер противодействия ей. Этой проблемой активно занимаются научные учреждения под эгидой $\mathrm{OOH}$, мирового криминологического общества и иных международных и национальных организаций. В связи с этим происходит активный процесс развития мировой криминологической теории, в которой стираются национальные грани и вырабатываются новые интернациональные криминологические идеи. Поэтому можно предположить, что транснациональность и глобализация преступности в отдаленной перспективе непременно приведут к интернационализации многонациональной криминологической науки.

Развитие криминологической науки повлекло за собой увеличение объемов криминологической информации и формирование основ криминологической классификации и систематизации накопленных знаний, которые бы способствовали адекватному использованию криминологических понятий и терминов, устранению неоднозначности языка криминологической науки. В результате чего криминологическая теория в качестве одного из оснований деления, пред- ложенного Р. Мертеном, ${ }^{1}$ стала разделяться на общетеоретические теории, частные криминологические теории и криминологические отрасли. Систематизация криминологических знаний привела к началу формирования внутри криминологии значительного количества частных криминологических теорий и криминологических отраслей, изучающих отдельные виды преступности и сферы их распространения. К таким развивающимся частным криминологическим теориям была отнесена и политическая криминология, изучающая взаимосвязь и взаимозависимость политики и преступности. ${ }^{2}$ Хотя исследования, посвященные этой проблематике, проводились специалистами различных государств и различных отраслей гуманитарного знания значительно раньше, чем было объявлено о необходимости формирования политической криминологии. Наиболее известной мировому криминологическому сообществу является работа итальянских криминологов Ч. Ломброзо и Р. Ляски «Политическая преступность и революция по отношению к праву, уголовной антропологии и го-

\footnotetext{
${ }^{1}$ Цит. по: Комлев Ю.Ю., Сафиуллин Н.Х. Социология девиантного поведения: Учебное пособие / Под общ. ред. Ю.Ю.Комлева. - 2-е изд., перераб. и доп. - Казань: КЮИ МВД России, 2006. - C.20.

${ }^{2}$ Шестаков Д.А. Понятие, предмет, система и перспективы криминологии // Криминология. Общая часть: Учебник / Под ред. В.В. Орехова. - СПб.: Изд-во СПбУ, 1992. - С.10.
} 
сударственной науке», опубликованная в 1890 году, а в последующем переведенная на многие языки народов мира, в том числе и русский, ${ }^{3}$ получившая широкий общественный резонанс и неоднозначные оценки среди ученых и политиков. ${ }^{4}$ Именно с этого произведения, на наш взгляд, началось активное исследование криминологических аспектов криминализации политических явлений и процессов в обществе. Разумеется, год выхода в свет этого произведения итальянских криминологов можно считать началом её зарождения, становления, формирования и развития как мирового научного направления по изучению устойчивых связей между преступностью и политикой. Хотя имеются и другие точки зрения на момент зарождения зарубежной политической криминологии (криминологии политической преступности). ${ }^{5}$ Необходимо отметить, что каждая страна имеет собственную историю развития и трансформации политико-криминологических идей, воззрений и теорий, которых сейчас накопилось достаточное количество. Политическая криминология конца XIX века и даже конца XX века существенно отличается от политической криминологии начала XXI века. Это объясняется её постоянным и последовательным развитием, хотя темпы развития политическо-криминологических воззрений и доктрин в разное время и в разных государствах не одинаковы. Не одинаковы и представления специалистов о месте политической криминологии в системе гуманитарных наук, её предметных границах, основных целях и задачах.

В современных гуманитарных науках политическую криминологию рассматривают как минимум с четырех позиций. Одни специалисты рассматривают её как относительно самостоятельное отраслевое направление криминологической теории. ${ }^{6}$ Вторые как одно из пер-

${ }^{3}$ Ломброзо Ч., Ляски Р. Политическая преступность и революция по отношению к праву, уголовной антропологии и государственной науке. В 2-х частях. - Санкт-Петербург, 1906; Ломброзо Ч., Ляски $P$. Политическая преступность и революция по отношению к праву, уголовной антропологии и государственной науке/ Предисловие проф. А.И. Исаева. - СПб., 2003.

${ }^{4}$ Каутский К. Природа политический преступлений. - Киев: Типография Ф.А. Борисова, 1905. - 14 с.; Его же. Генезис политических преступлений // Проблемы марксизма. Сборник второй: Проблемы преступности / Под ред. и с предисловием Я.С. Розанова. - Киев, 1924. - С.43-57; Гроссе Ф. К вопросу о природе политических преступлений // Проблемы марксизма. Сборник второй: Проблемы преступности / Под ред. и с предисловием Я.С. Розанова. - Киев, 1924. - C.58-68.

${ }^{5}$ Гилинский Я.И. Девиантология: социология преступности, наркотизма, проституции, самоубийств и других «отклонений». 2-е изд., испр. и доп. - СПб., 2007. - С.105.

${ }^{6}$ Carlen P. Jigsaw: a political criminology of youth homeless ness. Vinton Keynes: Open University press, 1996. - P.7-8; Шестаков Д.А. спективных направлений современной политологии, ${ }^{7}$ в частности такого крупного научного направления как политика права, формирующейся на стыке политики и права. ${ }^{8}$ Третьи убеждены в том, что политическая криминология - это частная социологическая теория такого крупного направления как социология политики, формирующаяся на стыке криминологии и государственной теории. ${ }^{9}$ Четвертые, рассматривают политическую криминологию как направление политической пропаганды (риторики) или политической лингвистики. ${ }^{10}$ Очевидная многоликость мировой политической криминологии обусловлена спецификой её исследования специалистами различных отраслей гуманитарного знания - криминологами, философами, социологами, политологами, психологами, филологами и т.д.

Мировые закономерности развития криминологии характерны и для российской криминологической науки, которая получила развитее во второй половине $\mathrm{XX}$ века в связи с интенсивным ростом преступности и низкой эффективностью противодействия ей со стороны государства и общества. В это время были сформулированы базовые криминологические категории, составляющие ее основной предмет: преступность, ее причины, личность преступника, предупреждение преступности. Внутри отечественной криминологии стали формироваться новые частные научные направления (криминологические теории), изучающие отдельные виды преступности. К таким развивающимся частным криминологическим теориям в конце прошлого века профессором Д.А. Шестаковым было предложено отнести и политическую криминологию, изучающую взаимосвязь и взаимозависимость политики и преступности. ${ }^{11}$ Эта инновационная идея

Отрасли российской криминологии: политическая криминология // Криминология: Учебник для юридических вузов / Под ред. В.Н. Бурлакова, В.П. Сальникова, С.В. Степашина. - СПб.: Издво «Лань», 1999. - С.60-65; Дремин В.Н. К вопросу о предмете институциональной криминологии: от криминальных практик к социальному институту // Митна справа. - 2010. - №6(72). - С.69.

${ }^{7}$ Воротников В.П. Теневизация общества: особенности российского политического процесса // Вестник Российского университета дружбы народов. - Серия: Политология. - 2004. - №1(5). - С.29-38.

${ }^{8}$ Scheingold S. A. Constructing the New Political Criminology: Power, Authority, and the Post-Liberal State // Law and Social inquiry. - 1998. - №1. - C.857-895.

${ }^{9}$ Markantonatou M. The Modernisation Process of Official Social Control: Transformations of Social Control in the Frame of Neoliberalism, Aspects of Political Criminology. - Max Planck Society, 2005.

${ }^{10}$ Elisaberg $V$. Linguistics and Political Criminology // Journal of Criminal Psychology. - 1944. - №5. - C.769-774.

${ }^{11}$ Шестаков Д.А. Понятие, предмет, система и перспективы криминологии // Криминология. Общая часть: Учебник / Под ред. В.В. Орехова. - СПб.: Изд-во СПбУ, 1992. - С.10. 


\section{Право и политика 7 (163) 2013}

в последующем, хотя и не сразу, нашла поддержку среди отечественных специалистов. ${ }^{12}$ Хотя следует отметить, что среди отечественных криминологов не все разделяли и разделяют подобные взгляды. Имеется целая группа специалистов, полагающих, что деление криминологии на отрасли и частные криминологические теории имеет существенный недостаток - ведет к «размыванию» предмета криминологии. В некоторых случаях утверждая при этом, что предмет политической криминологии - взаимосвязь преступности и политики, больше относится к проблемам политических наук, чем к криминологической теории.

Формирование и развитие российской политической криминологии как нового научного направления было обусловлено рядом объективных обстоятельств. Во-первых, снятием идеологическим догм с криминологических исследований постсоветского периода. Во-вторых, осознанием специалистами того, что в условиях реформирования российской государственности политическая сфера жизнедеятельности не менее криминализирована, чем другие. В-третьих, необходимостью криминологической оценки последствий массовых политических репрессий - противоправной деятельности высших должностных лиц Советского государства. В-четвертых, появлением целого ряда научных (криминологических, политологических, социологических, исторических, философских и иных) работ, в которых утверждалось о наличии в обновляющемся российском обществе политической преступности или её отдельных видов. В-пятых, активным формированием и развитием мировой политической криминологии зарубежными научными и образовательными учреждениями и их специалистами, как одного из наиболее перспективных научных направлений. ${ }^{13}$ В-шестых, начатой подготовкой зарубежными образовательными учреждениями научно-педагогических кадров - магистров криминологии по специальности «Политическая криминология» (Universidat Autonoma de Nuevo Leon

\footnotetext{
${ }^{12}$ См., например: Колесников В.В. Экономическая преступность и рыночные реформы: политико-экономические аспекты. - СПб.: Изд-во СПбУЭФ, 1994. - С.35; Александрова Н.С., Бурлаков В.Н., Шестаков Д.А. Проблемы экономической криминологии // Правоведение. - 1998. - №1. - С.224; Тенчов Э.С., Степанова И.Б. Рецензия на книгу: Криминология: Учебник для юридических вузов / Под ред. В.Н. Бурлакова, В.П. Сальникова, С.В. Степашина. - СПб: Санкт-Петербургский ун-т МВД России, 1999. - 608 с. // Правоведение. - 2000. - №1. - С.287; Кабанов П.А. Политическая криминология - новое научное направление в отечественной криминологии (ее предмет и система) // Следователь. - 1999. - №1. - С.53-57; Милюков С.Ф. Российское уголовное законодательство: опыт критического анализа: Монография. - СПб., 2000. - С.260261 и другие.

${ }^{13}$ Eskridge Ch.W. The State of the Field of Criminology // Journal of Contemporaru Criminal Justice. - 2005. - Vol.21 - №4. - C.296-308.
}

UANT). ${ }^{14}$ И как закономерный итог, - к началу XXI века отечественными специалистами, изучающими криминогенные процессы в политической сфере жизни общества, были проведены крупные научные исследования феномена политической преступности, по результатам которых было опубликовано более полусотни научных статей и сообщений, так или иначе связанных с рассмотрением отдельных аспектов взаимосвязи преступности и политики. В результате чего политическая криминология, наравне с экономической и семейной криминологией, криминологией средств массовой информации и виктимологией, была объявлена отраслью российской криминологической науки, внутри которой формируются собственные научные направления, составляющие ее основной предмет. ${ }^{15} \mathrm{~K}$ этому же мнению пришли и зарубежные криминологи, исследующие отдельные аспекты национальной уголовной политики. ${ }^{16}$ И, как нам представляется, именно с этого времени, политико-криминологические исследования криминализации и декриминализации политической сферы жизни российского общества получили право на относительную отраслевую самостоятельность и дальнейшее поступательное развитие.

В начале текущего века интерес к основным проблемам российской политической криминологии среди отечественных и зарубежных специалистов не уменьшается, а, наоборот, постоянно увеличивается. Об этом свидетельствует хотя бы тот факт, что спрос на учебную и учебно-методическую литературу за последние несколько лет по данной отрасли криминологических знаний значительно возрос, а количество научных исследований и опубликованных по ним результатов - возрастает.

Необходимо отметить, что только с начала текущего века (в 2001 - 2012 гг.) отечественными специалистами в области криминологии и других отраслей гуманитарного знания подготовлен и опубликован ряд новых, оригинальных по своему содержанию, научных, учебных и учебно-методических работ. Эти работы характеризуют состояние российской политической криминологии современного периода и существенно дополняют ранее опубликованные научные исследования по проблемам противодействия преступности в политической сфере жизни общества и её теоретическим аспектам.

\footnotetext{
${ }^{14}$ www. uant.mx/international/master.html

${ }^{15}$ Шестаков Д.А. Отрасли российской криминологии: политическая криминология // Криминология: Учебник для юридических вузов / Под ред. В.Н. Бурлакова, В.П. Сальникова, С.В. Степашина. - СПб.: Изд-во «Лань», 1999. - С.60-65.

${ }^{16}$ Carlen P. Jigsaw: a political criminology of youth homeless ness. Vinton Keynes: Open University press, 1996. - P.7-8.
} 
Формирование и развитие основ российской политической криминологии в наступившем веке происходит динамично и достаточно успешно. Такое развитие обусловлено как вниманием криминологов к исследованию феномена политической преступности и её отдельных видов, так и научными исследованиями специалистов иных отраслей знания, связанных с оценкой девиантного поведения в политической сфере жизнедеятельности. В результате проведенных научных исследований политических девиаций отечественными специалистами были подготовлены и успешно защищены более десятка диссертаций (Н.В. Башкиров, ${ }^{17}$ И.В. Воронов, ${ }^{18}$ О.В. Кнительшот, ${ }^{19}$ М.Е. Косякова, ${ }^{20}$ Н.Н. Кудрина, ${ }^{21}$ М.И. Лабунец, ${ }^{22}$ Р.И. Мороз, ${ }^{23}$ И.А. Сазонов, ${ }^{24}$ А.С. Семынин, ${ }^{25}$ В.Н. Янгол ${ }^{26}$ и др.), которые способствовали развитию этой отрасли криминологических знаний. Однако, наибольшее развитие российская политическая криминология получила за счет собственных научных исследований и некоторых наиболее важных исследований в области права и политологии. На них следует остановиться отдельно.

В апреле 2002 года в Рязанской академии права и управления Министерства юстиции России препо-

17 Башкиров Н.В. Меры административно-правового противодействия политическому экстремизму: Дисс. .. кандид. юрид. наук. - М., 2005.

${ }^{18}$ Воронов И.В. Основы политико-правового ограничения социально-политического экстремизма как угрозы национальной безопасности Российской Федерации: Дисс. кандид. полит. наук. - M., 2003.

${ }^{19}$ Кнительшот О.В. Система противодействия политическому экстремизму в современном обществе: Автореф. дисс. ... кандид. социолог. наук. - Саратов, 2006.

${ }^{20}$ Косякова М.Е. Правовая превенция политического экстремизма: институциально-технологический аспект: Автореф. дисс. ... кандид. юрид. наук. - Ростов-на-Дону, 2008.

${ }^{21}$ Кудрина Н.Н. Политический терроризм: сущность, формы проявления, меры противодействия: Дисс. ... кандид. полит. наук. - СПб., 2000.

22 Лабунеи М.И. Политический экстремизм: этоннациональная регионализация: Дисс. ... кандид. полит. наук. - Ростов-на-Дону, 2002.

${ }^{23}$ Мороз Р.И. Терроризм как форма политического экстремизма: тенденции развития в 1990-2004 гг.: Дисс. ... кандид. полит. наук. - M., 2004.

${ }^{24}$ Сазонов И.А. Природа и исторические формы политического экстремизма. На примере политического развития России в XX веке: Дисс. ... кандид. полит. наук. - М., 2004.

${ }^{25}$ Семынин А.С. Противодействие политической коррупции политико-правовыми средствами в государствах Евросоюза (опыт Финляндии и Эстонии): Автореф. дисс. ... кандид. политолог. наук. - Казань, 2009.

${ }^{26}$ Янгол В.Н. Оперативно-розыскное противодействие политическому терроризму: Дисс. ... кандид. юрид. наук. - СПб., 2006. давателем Владимирского юридического института Минюста России А.Ф. Кулаковым была защищена первая кандидатская диссертация по криминологии на тему: «Политическая преступность: криминологический и правовой аспекты», в которой автором дано собственное оригинальное определение политической преступности, вскрыты основные причины ее существования и воспроизводства, а также предложены некоторые меры по сдерживанию политической преступности на социально терпимом уровне. ${ }^{27}$

Наиболее успешным в формировании основ и развитии отечественной политической криминологии стал 2008 год на протяжении, которого было защищено четыре диссертационных исследования по наиболее актуальным проблемам исследования политической преступности и выработке мер противодействия ей.

В феврале 2008 года на политологическом факультете МГУ Д.А. Квон была защищена первая кандидатская диссертация по политологии на тему: «Политическая преступность: проблема концептуализации и актуальные практики», в которой в рамках синергетического подхода рассмотрены основные теоретические проблемы современной российской криминологии политической преступности, а точнее её электоральной составляющей. ${ }^{28}$

В июне 2008 года в Московской государственной юридической академии О.Ю. Антоновым была защищена докторская диссертация по криминалистике на тему: «Теория и практика выявления и расследования электоральных преступлений». В этой оригинальной работе были рассмотрены криминалистические проблемы повышения эффективности противодействия электоральной преступности в современном российском обществе. ${ }^{29}$

В октябре 2008 года в Уральской государственной юридической академии (г. Екатеринбург) автором настоящей работы была защищена докторская диссертация по криминологии на тему: «Политическая преступность: понятие, сущность, виды, причины, личность политического преступника, меры противодействия (криминологическое исследование)», в которой предложена авторская концепция политической преступности и мер предупредительного воздействия

\footnotetext{
${ }^{27}$ Кулаков А.Ф. Политическая преступность: криминологический и правовой аспекты: Дисс. ... кандид. юрид. наук. - Рязань, 2002. $-158 \mathrm{c}$.

${ }^{28}$ Квон Д.А. Политическая преступность: проблема концептуализации и актуальные практики: Автореф. дисс. ... кандид. полит. наук. - М., 2008. - 24 с.

${ }^{29}$ Антонов О.Ю. Теория и практика выявления и расследования электоральных преступлений: Автореф. дисс. ... доктора юрид. наук. - М., 2008. - 53 с.
} 


\section{Право и политика 7 (163) • 2013}

на неё, а также предложены некоторые перспективные направления развития отечественной и мировой политической криминологии. ${ }^{30}$

В второй половине декабря 2008 года в СанктПетербургском университете МВД России адъюнктом этого образовательного учреждения А.П. Даниловым была защищена кандидатская диссертация по уголовному праву и криминологии на тему: «Убийства по политическим мотивам в современной России (криминологический и уголовно-правовой аспекты)», в которой автором был проведен политико-криминологический анализ политических убийств в условиях реформирования России и предложен механизм противодействия им в современных условиях. ${ }^{31}$

В конце 2009 года в диссертационном совете политологического факультета Казанского государственного университета A.C. Семыниным была защищена кандидатская диссертация по политологии на тему: «Противодействие политической коррупции политико-правовыми средствами в государствах Евросоюза (опыт Финляндии и Эстонии)», в которой автором был проанализирован опыт противодействия политической коррупции в Финляндии и Эстонии и предложены некоторые меры по совершенствованию антикоррупционной политики этих государств. ${ }^{32}$ В последующем по вопросам описания и объяснения сущности политической коррупции, факторам её детерминирующим, а также мерам противодействия этому явлению современной политической жизни были защищены кандидатские диссертации по политологии Д.Б. Боталовой ${ }^{33}$ и Д.А. Зардания. ${ }^{34}$

Следует отметить то обстоятельство, что в начале наступившего века существенный вклад в развитие политической криминологии внесли сотрудники Научно-исследовательского института Академии Генеральной прокуратуры России, изучавшие про-

\footnotetext{
${ }^{30}$ Кабанов П.А. Политическая преступность: понятие, сущность, виды, причины, личность политического преступника, меры противодействия (криминологическое исследование): Дисс. ... доктора юрид. наук. - Казань, 2008. - 496 с.

${ }^{31}$ Данилов А.П. Убийства по политическим мотивам в современной России (криминологический и уголовно-правовой аспекты): Дисс. ... кандид. юрид. наук. - СПб., 2008.

${ }^{32}$ Семынин А.С. Противодействие политической коррупции политико-правовыми средствами в государствах Евросоюза (опыт Финляндии и Эстонии): Автореф. дисс. ... кандид. политолог. наук. - Казань, 2009. - 24 с.

${ }^{33}$ Боталова Д.Б. Сущность, особенности и факторы политической коррупции как неформального института в условиях системной трансформации российского общества: Дисс. ... кандид. полит. наук. - СПб., 2011.

34 Зардания Д.А. Политическая коррупция как форма теневой власти: Автореф. дисс. .... кандид. полит. наук. - Ростов-на-Дону, 2012.
}

блемы проникновения организованной преступности в политическую сферу жизни общества, о чем свидетельствуют их научные публикации. ${ }^{35}$ Однако, в последующим эта работа была свернута и результатов крупных научных исследований напрямую связанных с данной проблемой опубликовано не было. Хотя отдельные аспекты проблем политической преступности ими рассматривались в рамках исследования вопросов латентной преступности. ${ }^{36}$

Несмотря на увеличивающееся количество проводимых научных исследований и публикацию работ по наиболее актуальным проблемам современной российской политической криминологии, по-прежнему остается ряд крупных проблемных вопросов, на которые требуются научно обоснованные ответы. Разумеется, эти вопросы взаимосвязаны и взаимообусловлены между собой. На наш взгляд, их можно условно разделить на две крупные самостоятельные группы.

Первая группа вопросов сопряжена с рассмотрением общетеоретических проблем отечественной криминологии, без разрешения которых невозможно объективно рассматривать принципиальные вопросы не только российской политической криминологии, но и других формирующихся внутри ее отраслей криминологических знаний (криминальной виктимологии, семейной, экологической и экономической криминологии, криминологии СМИ, пенитенциарной криминологии, криминологии религии (крименотеологии), криминологии закона и др.).

Вторая группа вопросов связана с рассмотрением специфичных для отечественной политической криминологии теоретических проблем, без разрешения которых трудно определиться с содержанием ее основного предмета и задач, стоящих перед этой отраслью криминологических знаний.

Наиболее крупной общетеоретической проблемой для российской политической криминологии, как впрочем, и для других отраслей отечественной криминоло-

\footnotetext{
${ }^{35}$ Долгова А.И., Астанин В.В., Дзюба Д.И. и др. Деятельность организованной преступности в политической сфере жизни общества // Организованная преступность, миграция, политика / Под ред. А.И. Долговой. - М.: Российская криминологическая ассоциация, 2002. - С.62-90; Астанин В.В. Реагирование на проявления организованной преступной деятельности в сфере избирательных процессов // Реагирование на преступность: концепции, закон, практика. - М.: Российская криминологическая ассоциация, 2002. - С.188-191; Ильин О.С. Некоторые аспекты состояния организованной преступности в политической сфере жизни общества // Организованный терроризм и организованная преступность. - М.: Российская криминологическая ассоциация, 2002. - С.163-169.

${ }^{36}$ Иншаков С.М., Корсантия В.А., Максименко И.В. Латентность преступлений против государственной власти // Теоретические основы исследования и анализа латентной преступности: монография / под. ред. С.М. Иншакова. - М., 2011. - С.487-502
} 
гии, требующей детальной научной проработки, является ее статус в общей теории российской криминологической науки. Для этого необходимо определиться, чем именно она является: отраслью криминологии или только частной криминологической теорией? Вопрос трудный и практически не разработанный отечественными и зарубежными криминологами до настоящего времени. Одни специалисты, без научного объяснения причин, критериев и оснований полагают, что она, как и другие самостоятельные направления криминологических исследований, сформировавшиеся в процессе исторического развития, является частной криминологической теорией, ${ }^{37}$ другие - отраслью криминологических знаний, ${ }^{38}$ третьи - не обращая внимание на существование различий между ними называют ее и аналогичные по статусу направления - отраслевыми разделами криминологии, ${ }^{39}$ четвертые - специальными криминологическими теориями. ${ }^{40}$

На наш взгляд, перечисленные нами выше, существующие точки зрения не только не разъясняют суть и статус российской политической криминологии и аналогичных по своей природе научных направлений, но и еще больше запутывают рассмотрение данной проблемы. В результате чего возникает логическая цепь других закономерных вопросов. Например, как соотносятся между собой частные криминологические

\footnotetext{
${ }^{37}$ Криминология: Учебник / Под ред. В.Н. Бурлакова, Н.М. Кропачева. - СПб.: Питер, 2002. - С.16; Старков О.В. Истоки новых направлений в криминологии // Закономерности преступности, стратегия борьбы и закон / Под ред. проф. А.И. Долговой. - М.: Российская криминологическая ассоциация, 2001. - С.516; Устинов В.С. Криминология. Общая часть: Учебное пособие. Н. Новгород, 2001. - С.21; Его же. Отечественная криминология XX века // Вестник Нижегородского университета им. Н.И. Лобачевского. Серия Право. Выпуск 2 (4). Государство и право: итоги ХХ века. - Н. Новгород: Изд-во ННГУ, 2001. - С.213; Гилинский Я.И. Криминология: Курс лекций. - СПб.: Питер, 2002. С.17; Бурлаков В.Н. Предмет, система и развитие криминологии // Криминология: Учебник / Под ред. В.Н. Бурлакова, Н.М. Кропачева. - СПб., 2003. - С.17; Горшенков Г.Н. Криминологический словарь. - Н. Новгород, 2007. - С.77.

${ }^{38}$ Криминология: Словарь / Под ред. В.П. Сальникова. - СПб.: Изд-во «Лань», 1999. - С.57; Криминология - ХХ век / Под ред. В.Н. Бурлакова, В.П. Сальникова. - СПб.: Изд-во «Юридический центр пресс», 2000. - С.9; Бурлаков В.Н. Краткое введение в криминологию // Криминология: Учебник / Под ред. В.Н. Бурлакова, Н.М. Кропачева. - СПб., 2005. - С.40; Шестаков Д.А. Введение в криминологию закона. - СПб.: Изд-во «Юридический центр пресс», 2011. - С.5.

${ }^{39}$ Номоконов В.А. Современная криминология: традиционные подходы и новые направления // Организованная преступность, миграция, политика / Под ред. проф. А.И. Долговой. - М.: Российская криминологическая ассоциация, 2002. - С.134.

${ }^{40}$ Клейменов М.П. Криминология: Учебник. - М.: Норма, 2008. - C.289.
}

теории и отрасли криминологии? Каковы объективные научные критерии их выделения в отечественной криминологии? ${ }^{41}$ Каково их место в общей системе криминологических знаний? И, наконец, как определить границы познания сложных политических явлений и процессов криминологическими средствами?

Для того чтобы ответить, хотя бы частично, на эти сложные общетеоретические вопросы, необходимо определиться с существующей в современном российском обществе криминологической терминологией, связанной с рассмотрением интересующих нас проблемных вопросов.

В современной отечественной криминологии под частной криминологической теорией (концепцией), в контексте рассматриваемой проблемы, принято понимать разновидность познания обособленных Особенной частью отдельных видов преступности, их причин, личности преступника, совершающего преступления данного вида, и меры предупреждения конкретного вида преступности, ${ }^{42}$ которые в реальной действительности образуют единый системный объект познания. ${ }^{43}$ Их многочисленность и разнообразие в современной отечественной и зарубежной криминологии не позволяет провести исчерпывающую и четкую классификацию всех криминологических теорий (концепций), тем более в рамках одной статьи, поэтому мы вынуждены отослать читателя к другим работам, в которых отражены наши взгляды на эту проблему. ${ }^{44}$

Несколько иначе обстоит дело с определением отрасли криминологической науки. В подготовленных отечественными и зарубежными специалистами юри-

\footnotetext{
${ }^{41}$ Тенчов Э.С., Степанова И.Б. Рецензия на книгу: Криминология: Учебник для юридических вузов / Под ред. В.Н. Бурлакова, В.П. Сальникова, С.В. Степашина. - СПб.: Санкт-Петербургский ун-т МВД России, 1999. - 608 с. // Правоведение. - 2000. - №1. - С.287.

${ }^{42}$ Горшенков Г.Н. Криминологический словарь. - Сыктывкар, 1995. - С.28-29; Криминология: Словарь / Под общ. ред. В.П. Сальникова. - СПб.: Изд-во «Лань», 1999. - С.64-65; Криминология / Под общ. ред. Ю.Ф. Кваши. - Ростов-на-Дону: Феникс, 2002. - С.36.

${ }^{43}$ Хохряков Г.Ф. Криминология: Учебник / Отв. ред. В.Н. Кудрявцев. - М.: Юристь, 1999. - С.79.

${ }^{44}$ Кабанов П.А. Структура криминологических знаний: диалектика развития и современное состояние: Лекция. - Нижнекамск: Нижнекамский филиал МГЭИ, 2005. - 39 с.; Его же. Систематизация и классификация криминологических знаний // Следователь. -2007. - №1. - С.35-41; Его же. Криминологическая таксономия: понятие, содержание, таксономические единицы и основания их группировки // Криминологический журнал Байкальского государственного университета экономики и права. - 2007. - №1-2. - С.25-29; Его же. Криминологическая таксономия: понятие, таксономические единицы, основания группировки // Преступность и проблемы борьбы с ней / Под общ. ред. А.И. Долговой, В.И. Каныгина. М.: Российская криминологическая ассоциация, 2007. - С.51-58.
} 


\section{Право и политика 7 (163) 2013}

дических, в том числе и криминологических словарях либо энциклопедиях, в силу новизны исследуемой проблемы, об отраслях криминологических знаний либо не упоминается, либо упоминается как бы вскользь, без глубокого всестороннего анализа данной проблемы и вычленения каких-либо признаков и оснований такого деления.

В тех немногочисленных ученых и научных работах отечественных криминологов, где упоминается об отраслях криминологии, ее понятие дается довольно пространно - как об относительно самостоятельной части науки криминологии. ${ }^{45}$ Столь общий подход к определению отрасли криминологических знаний не дает исчерпывающего ответа на поставленные вопросы. Поскольку относительно самостоятельной частью криминологической науки можно назвать и любую частную криминологическую теорию, изучающую отдельный вид преступности, а также и крупные общетеоретические разделы (теория причин преступности (этиология преступности), теория предупреждения преступности, антропология преступности).

Нам представляется, что отраслью криминологической науки можно назвать криминологическую теорию, изучающую закономерности преступного поведения, его причины и меры по его предупреждению в определенной специфичной сфере общественной деятельности, входящую как в общую теорию криминологии, так и в состав комплексных отраслевых теорий. При этом нужно иметь в виду, что отрасль криминологических знаний, в свою очередь, структурно должна состоять из нескольких взаимосвязанных частных криминологических теорий, изучающих отдельные виды преступности в этой сфере жизни общества. Например, в экономической криминологии помимо общих вопросов противодействия экономической преступности, следует выделять и исследовать ещё и частные направления. Таковыми на сегодняшний день являются налоговая и таможенная преступность. Разумеется, предлагаемое определение отрасли криминологии - лишь одно из многих возможных, но оно, как нам представляется, может, хотя и не в полной мере, отразить суть ее предмета и может служить основой для дальнейших исследований в этом направлении.

При предлагаемом подходе к определению отрасли криминологии можно легко дать дефиницию любой отрасли криминологических знаний. В нашем случае российскую политическую криминологию как отрасль криминологических знаний можно назвать криминологической теорией, изучающей закономерности существования преступности в политической сфере

${ }_{45}^{45}$ Криминология: Словарь / Под общ. ред. В.П. Сальникова. - СПб.: Изд-во «Лань», 1999. - С.57. жсизни общцества, ее причины, личностные характеристики тех, кто совершает преступления в этой сфере, их жертв, а также меры по ее предупреждению. Она является как составным элементом общей криминологической науки, так и соответствующим элементом политической науки. Внутри данной отрасли криминологии самостоятельно развиваются частные криминологические теории, изучающие различные виды преступности, проявляющиеся в политической сфере жизни общества: электоральная, бунтовская (криминальная конспирология ${ }^{46}$ ), международная, тоталитарная преступность, политический терроризм, криминальный политический рэкет, криминальный политический вандализм, политическая коррупция, злоупотребление властью в политических целях, информационная (массово-коммуникативная) политическая преступность. В результате интенсивного, творческого и последовательного их развития уже в первой половине текущего века можно прогнозировать выделение из российской политической криминологии несколько самостоятельных научных подотраслей криминологических знаний. Таковыми на наш взгляд могут стать:

a) политическая террорология - учение о терроре и терроризме как средствах решения политических проблем, их причинах, последствиях, особенностях личности террористов и диктаторов и мерах по их сокращению в будущей политической практике;

б) криминальная конспирология - учение о закономерностях развития и существования бунтовской преступности, её причинах, особенностях личности бунтаря и мерах по её предупреждению;

в) криминология международной политической преступности - учение о закономерностях существования и развития международной политической преступности, её причинах, особенности личности преступника и мерах по предупреждению этого вида преступности;

г) криминальная политическая виктимология - учение о жертвах политической преступности, в первую очередь, криминального политического экстремизма, их видах и выработке мер по их социальной реабилитации;

д) электоральная криминология - учение о закономерностях существования и развития электоральной преступности, её причинах, особенностях личности преступника и мерах по предупреждению этого вида преступности;

е) криминология политического мошенничества учение о закономерностях существования и развития

\footnotetext{
${ }^{46}$ Кабанов П.А. Криминальная конспирология: понятие и предмет // Криминологический журнал Байкальского государственного университета экономики и права. - 2008. - №3. - С.5-9.
} 
криминального политического мошенничества, его причинах, особенностях личности политического мошенника и мерах по его предупреждению;

ж) криминология политической коррупции учение о коррупционном поведении в политической сфере жизнедеятельности, её причинах, личности политического коррупционера и политического корруптёра, а также о мерах предупреждения политической коррупции;

3) криминология информационной (массово-коммуникативной) политической преступности - межотраслевое учение, изучающее информационную (массово-коммуникативную) политическую преступность, её причины, особенности личности информационного политического преступника, вырабатывающее меры по её предупреждению;

и) криминальная политическая этиология - учение о причинах политической преступности или отдельных её видов, теоретических основах классификации причин преступного поведения в политической сфере жизнедеятельности;

к) криминальная политическая антропология учение о личности политического преступника или отдельных его типах и видах в целях выработки адекватных мер воздействия на однородные группы лиц и исключения повторения преступного политического поведения в будущем. Между тем уже сейчас внутри них начинаются выделяться самостоятельные частные политико-криминологические теории. Например, в рамках криминальной политической виктимологии уже зарождаются виктимология тоталитаризма, виктимология терроризма и виктимология коррупции, исследующие соответствующие категории жертв (политических репрессий, жертв политически мотивированных терроризма и коррупции).

Предложенный подход позволяет увидеть взаимоотношение частных криминологических теорий и отраслей криминологии, а также дифференцировать криминологические знания, поскольку те и другие, на наш взгляд, представляют собой самостоятельные разделы единой криминологии. Поэтому отрасли криминологии и частные криминологические теории целесообразно анализировать в Особенной части криминологии, а принципы, критерии, основания и методику их выделения и иные общетеоретические проблемы - в Общей части. В результате такого подхода ставятся под сомнение продолжающиеся рассуждения о междисциплинарности современной российской политической криминологии.

Вторая общетеоретическая проблема российской политической криминологии заключается в ее статусе как учебной дисциплины. При этом некоторыми отечественными специалистами указывается на то обстоятельство, что ее отдельное преподавание как самостоятельной учебной дисциплины не целесообразно, поскольку приводит к расколу единой криминологической науки и одноименной учебной дисциплины. В связи с этим вполне заслуженно ставится вопрос о преподавании этой дисциплины в качестве специального курса, направленного на дополнительное получение криминологических знаний о политической преступности, закономерностях ее воспроизводства и существования, а также мерах по ее сдерживанию на социально терпимом уровне. ${ }^{47}$ Хотя именно как специальный факультативный курс, направленный на углубленное изучение политологии и криминологии, «Политическая криминология» преподавался на юридическом факультете Нижнекамского филиала Московского гуманитарно-экономического института и других учебных заведениях с 1998 года по 2000 год. При этом не исключается, что отдельные виды преступности в сфере политики могут рассматриваться или уже рассматриваются отдельными (самостоятельными) темами в учебниках по криминологии. Например, отдельные криминологические аспекты политической преступности уже на протяжении нескольких последних лет рассматриваются в ряде учебников и учебных пособий по криминологии для юридических вузов и факультетов. ${ }^{48}$ Нам представляется, что «дробление» криминологии, в том числе и политической криминологии явление закономерное, которое вызвано множеством факторов. Основным из них, на наш взгляд, являются интересы потребителя криминологической информации. Например, Центральной избирательной комиссии РФ, при проведении курсов повышения квалификации членов территориальных избирательных комиссий, как правило, имеющих высшее про-

\footnotetext{
47 См., например: Долгова А.И. Закономерности преступности, борьба с ней и научное обеспечение борьбы // Закономерности преступности, стратегия борьбы и закон / Под ред. проф. А.И. Долговой. - М., 2001. - С.40; Ее же. Теоретические проблемы криминологии как науки // Предупреждение преступности. -2001. - №1. - С.49; Ее же. Виды преступности или виды криминологии? // Криминология: Учебник для юридических вузов / Под ред. проф. А.И. Долговой. - М., 2001. - С.499.

${ }^{48}$ Криминология: Учебник / Под ред. акад. В.Н. Кудрявцева и проф. В.Е. Эминова. - М., 1999. - С.310-338; Иншаков С.М. Криминология: Учебник. - М., 2000. - С.214-230; Его же. Криминология в схемах и определениях: Учебное пособие. - М., 2001. - С.157-162; Его же. Криминология: Практикум. - М., 2001. - С.165-172; Его же. Криминология: Вопросы и ответы. - М., 2002. - С.118-123; Гилинский Я.И. Криминология: Курс лекций. - СПб., 2002. - С.242248; Криминология: Учебник / Под ред. Г.А. Аванесова. 3-е изд., перераб. и доп. - М., 2005. - С.427-440; Егоров В.А. Преступность в России на рубеже веков: Учебное пособие. - Йошкар-Ола, 2007. - C.30-34; Лунеев В.B. Курс мировой и российской криминологии. В 2 т. Т.ІІ. Особенная часть. - М., 2011. - С.56-263.
} 


\section{Право и политика 7 (163) • 2013}

фессиональное юридическое образование необходимо преподавать основы электоральной криминологии, изучающую особенности и меры противодействия преступности в условиях избирательных процессов, а не всю криминологию, которую они проходили ещё в вузе. В этом плане это направление политической криминологии носит прикладной характер, так как обслуживает интересы правоприменительного или контролирующего государственного органа (заказчика).

К наиболее крупным неразрешенным «внутренним» проблемным вопросам современной российской политической криминологии относится определение границ ее предмета, поскольку взгляды на его (предмет политической криминологии) объем и содержание у отечественных криминологов различны. Одни специалисты рассматривают ее в узком смысле, как криминологическую теорию, занимающуюся изучением закономерностей развития политической преступности и выработкой общесоциальных и специальных мер, направленных на ее предупреждение. Другие специалисты рассматривают предмет политической криминологии в самом широком смысле как деятельность в сфере политики, направленную как на анализ преступности в этой сфере, так и на выработку и анализ политических решений по сдерживанию преступности. Третьи - ограничиваются лишь изучением закономерностей существования и развития преступности в политической сфере жизни общества и выработкой мер по ее сдерживанию на социально терпимом уровне.

Так, авторитетный российский криминолог профессор А.И. Долгова, на основе логического анализа отдельных ранних учебных и научных работ автора настоящего раздела учебника, считает, что предметом политической криминологии является политическая преступность, ее причины, личность политического преступника и меры ее предупреждения. ${ }^{49}$ Подобных же взглядов на предмет политической криминологии придерживается и другой российский исследователь — А.Ф. Кулаков. ${ }^{50}$

Основоположник российской политической криминологии профессор Д.А. Шестаков в своем учебнике «Криминология. Преступность как свойство общества» указывает, что предмет политической криминологии объединяет исследование следующих взаимосвязанных проблем: политической преступности, которая складывается из воспроизводства преступлений как самого государства (преступной политики), так и против государства и его конституционного строя;

49 Долгова А.И. Указ. работы.

${ }^{50}$ Кулаков А.Ф. Политическая преступность: криминологический и правовой аспекты: Дисс. ... кандид. юрид. наук. - Рязань, 2002. - C.6. влияния тоталитарной политики на общеуголовную преступность; криминологическую политику; использование темы преступности в политических целя ${ }^{51}$ (политические спекуляции проблемой преступности ${ }^{52}$ ).

Третьи специалисты, полагают, что наравне с указанными направлениями предмета политической криминологии в неё входят, криминологическая политология - отрасль криминологического знания о государственной политике (доктрине) борьбы с преступностью и криминологическая кратология - формирующаяся концепция, изучающая возможности и условия использования властных способностей и возможностей государства в преступных целях и вопросы их предупреждения. ${ }^{53}$

Четвертые, рассматривая отдельные политические аспекты существования и воспроизводства преступности в условиях избирательных процессов в современном российском обществе, справедливо очерчивают границы предмета российской политической криминологии изучением проблем существования, воспроизводства и предупреждения преступности в политической сфере жизни общества. ${ }^{54}$

На наш взгляд, из всех существующих подходов к криминологическому анализу предмета российской политической криминологии, предпочтительнее выглядит четвертая точка зрения. Действительно, в предмет российской политической криминологии должны входить те же самые элементы, что и в предмет общей теории криминологии, но только проявляющиеся в специфичной политической сфере жизни общества. Это означает, что в российской политической криминологии необходимо творческое использование основных концепций и аналитических инструментов (методов познания) криминологии для анализа степени криминализации политической сферы жизнедеятельности и выработке механизмов по её ограждению и очищению от преступных проявлений.

Как нам представляется, наравне с указанными нами проблемами российской политической криминологии необходимо дополнительное научное по-

${ }^{51}$ Шестаков Д.А. Криминология. Преступность как свойство общества: Краткий курс. - СПб.: Изд-во «Лань», 2001. - С.202.

52 Дикаев С.У. Рецензия на книгу: Шестаков Д.А. Криминология. Преступность как свойство общества: Краткий курс. - СПб.: Изд-во «Лань», 2001. - 260 с. // Предупреждение преступности. - 2002. - №1. - C.70.

${ }_{53}$ Горшенков Г.Н. Криминологический словарь. - Н. Новгород, 2007. - C.46-47, 104-105.

${ }^{54}$ Груздева А.П. О месте преступлений, совершаемых в условиях избирательного процесса в системе отечественной криминологии // Актуальные вопросы экономики и права в современной России: Сборник научных трудов. Вып.3. - Нижнекамск: Нижнекамский филиал МГЭИ, 1999. - С.41-43. 
знание некоторых иных крайне необходимых для ее последующего развития: методику и методологию исследований, используемых в российской политической криминологии; историю изучения преступности в сфере политики и мер реагирования на нее в России; изучение преступности в политической сфере жизни общества и мерах реагирования на нее за рубежом (зарубежная политическая криминология).

Необходимо отметить то обстоятельство, что начинает привлекать внимание специалистов в области криминологии функционирование преступности в органах государственной власти и местного самоуправления, а изучение преступности как элемента политической системы, - предложенное профессором Г.Н. Горшенковым, ${ }^{55}$ займет достойное место в российской политической криминологии, возможно, и в качестве одного из научных направлений, входящих в её предметное поле.

Определившись с понятием, содержанием, структурой и предметом современной политической криминологии необходимо обратить внимание на основные цели и задачи, стоящие перед ней. Мировой и отечественный опыт развития политической криминологии позволяет предположить, что основной прикладной целью современной российской политической криминологии является разработка обоснованных положений, направленных на снижение криминализации политической сферы жизнедеятельности путем совершенствование системы предупредительного воздействия на преступность в этой сфере. Основной теоретической целью этой отрасли криминологических знаний является объективная и адекватная оценка степени криминализации политической системы общества, оценка и анализ причин такого положения дел и разработка теоретических моделей системы эффективного противодействия преступности в этой сфере.

В качестве перспективных задач современной российской политической криминологии отечественные специалисты, в зависимости от своих научных пристрастий и интересов, обычно выделяют следующие: a) осмысление объема и сущности преступности в политической сфере жизни общества; ${ }^{56}$ б) криминологическую оценку ленинского и сталинского тер-

${ }^{55}$ Горшенков Г.Н. Политический режим, средства массовой информации и преступность // Политический режим и преступность / Под ред. В.Н. Бурлакова, Ю.Н. Волкова, В.П. Сальникова. - СПб., 2001. - С.125-136; Горшенков А.Г., Горшенков Г.Г., Горшенков Г.Н. Преступность как элемент политической системы // Вестник научных трудов Нижнекамского филиала Московского гуманитарно-экономического института. Вып.3. Часть 2: Вопросы борьбы с преступностью. - Нижнекамск, 2001. - С.9-17.

${ }^{56}$ Шестаков Д.А. Криминология. Преступность как свойство общества: Краткий курс. - СПб.: Изд-во «Лань», 2001. - С.202. pора $^{57}$ либо других диктаторских или тоталитарных режимов, ${ }^{58}$ в том числе и иных политических преступлений (захватнических войн ${ }^{59}$ ). Однако, представленные направления являются лишь частью основных задач, стоящих перед политической криминологией. Нам представляется, с учетом современного состояния российской и мировой политической криминологии, в перечень её основных задач должны входить несколько сложных взаимосвязанных и взаимообусловленных вопросов. Во-первых, необходим политико-криминологический мониторинг состояния преступности в политической сфере жизни общества и её отдельных видов или форм проявления как на национальном, так и на международном уровнях (тенденции и закономерности развития). Во-вторых, необходимы исследования личности политического преступника и его отдельных типов и видов. В-третьих, должны быть выработаны критерии (количественные и качественные показатели) объективной оценки негативных социальных последствий преступного поведения в политической сфере жизни деятельности - определение её «цены» для государства и общества. В-четвертых, крайне важны для развития политической криминологии выявление, фиксация и оценка основных причин, способствующих криминализации политической сферы жизни современного общества. В-пятых, требуется продолжение исследования жертв политически мотивированного преступного поведения и выработка мер виктимологической реабилитации и виктимологической профилактики. В-шестых, назрела научная разработка предложений по совершенствованию системы мер, направленных на противодействие криминализации политической сферы жизнедеятельности с учетом изменяющейся политической ситуации в обществе.

Изложенное выше позволяет нам сделать вывод о том, что мировая и российская политическая криминология - сложное и многоликое научное направление. Её международный и национальный статус среди наук зависим, чаще всего, от субъективных пристрастий исследователей и ими же определяется. В российской науке статус политической криминологии тоже не вполне определен. Однако, большинством специалистов она рассматривается как частное направление отечественной криминологии, зародившееся в начале 90-х годов XX века в результате криминологического осмысления

\footnotetext{
57 Там же.

${ }^{58}$ Гилинский Я.И. Криминология: теория, история, эмпирическая база, социальный контроль. 2-е изд., перераб. и доп. - СПб., 2009. - C.326.

59 Оболонский A.B. Геополитика - аморальный вид ложного сознания и цивилизационные альтернативы // Политическая концептология. - 2010. - №1. - С.54.
} 


\section{Право и политика 7 (163) 2013}

отечественными учеными преступных злоупотреблений высших должностных лиц Советского государства. Однако под воздействием развития мировой политической криминологии и собственному развитию к началу XXI века значительно расширила предмет исследовательского поиска и в настоящее время отечественными криминологами рассматривается как перспективная и быстро развивающаяся отрасль российской криминологической науки.

\section{Библиография:}

1. Carlen P. Jigsaw: a political criminology of youth homeless ness. - Vinton Keynes: Open University press, 1996.

2. Elisaberg V. Linguistics and Political Criminology // Journal of Criminal Psychology. - 1944. - №5.

3. Eskridge Ch.W. The State of the Field of Criminology // Journal of Contemporaru Criminal Justice. - 2005. - Vol.21. - №4.

4. Markantonatou M. The Modernisation Process of Official Social Control: Transformations of Social Control in the Frame of Neoliberalism, Aspects of Political Criminology. - Max Planck Society, 2005.

5. Scheingold S. A. Constructing the New Political Criminology: Power, Authority, and the Post-Liberal State // Law and Social inquiry. - 1998. - №1.

6. Александрова Н.С., Бурлаков В.Н., Шестаков Д.А. Проблемы экономической криминологии // Правоведение. - 1998. - №1.

7. Антонов О.Ю. Теория и практика выявления и расследования электоральных преступлений: Автореф. дисс. ... д-ра юрид. наук. - М., 2008.

8. Астанин В.В. Реагирование на проявления организованной преступной деятельности в сфере избирательных процессов // Реагирование на преступность: концепции, закон, практика. - М.: Российская криминологическая ассоциация, 2002.

9. Башкиров Н.В. Меры административно-правового противодействия политическому экстремизму: Дисс. .. кандид. юрид. наук. - М., 2005.

10. Боталова Д.Б. Сущность, особенности и факторы политической коррупции как неформального института в условиях системной трансформации российского общества: Дисс. ... кандид. полит. наук. - СПб., 2011.

11. Воронов И.В. Основы политико-правового ограничения социально-политического экстремизма как угрозы национальной безопасности Российской Федерации: Дисс. кандид. полит. наук. - М., 2003.

12. Воротников В.П. Теневизация общества: особенности российского политического процесса
// Вестник Российского университета дружбы народов. - Серия: Политология. - 2004. - №1(5).

13. Гилинский Я.И. Девиантология: социология преступности, наркотизма, проституции, самоубийств и других «отклонений». 2-е изд., испр. и доп. - СПб., 2007.

14. Гилинский Я.И. Криминология: теория, история, эмпирическая база, социальный контроль. 2-е изд., перераб. и доп. - СПб., 2009.

15. Горшенков А.Г., Горшенков Г.Г., Горшенков Г.Н. Преступность как элемент политической системы // Вестник научных трудов Нижнекамского филиала Московского гуманитарно-экономического института. Вып.3. Часть 2: Вопросы борьбы с преступностью. - Нижнекамск, 2001.

16. Горшенков Г.Н. Политический режим, средства массовой информации и преступность // Политический режим и преступность / Под ред. В.Н. Бурлакова, Ю.Н. Волкова, В.П. Сальникова. - СПб., 2001.

17. Горшенков Г.Н. Криминологический словарь. Н. Новгород, 2007.

18. Гроссе Ф. К вопросу о природе политических преступлений // Проблемы марксизма. Сборник второй: Проблемы преступности / Под ред. и с предисловием Я.С. Розанова. - Киев, 1924.

19. Груздева А.П. О месте преступлений, совершаемых в условиях избирательного процесса в системе отечественной криминологии // Актуальные вопросы экономики и права в современной России: Сборник научных трудов. Вып.3. - Нижнекамск: Нижнекамский филиал МГЭИ, 1999.

20. Данилов А.П. Убийства по политическим мотивам в современной России (криминологический и уголовно-правовой аспекты): Дисс. ... кандид. юрид. наук. - СПб., 2008.

21. Дикаев С.У. Рецензия на книгу: Шестаков Д.А. Криминология. Преступность как свойство общества: Краткий курс. - СПб.: Изд-во «Лань», 2001. - 260 с. // Предупреждение преступности. - 2002. - №1.

22. Долгова А.И. Теоретические проблемы криминологии как науки // Предупреждение преступности. - 2001. - №1.

23. Долгова А.И., Астанин В.В., Дзюба Д.И. и др. Деятельность организованной преступности в политической сфере жизни общества // Организованная преступность, миграция, политика / Под ред. А.И. Долговой. - М.: Российская криминологическая ассоциация, 2002.

24. Дремин В.Н. К вопросу о предмете институциональной криминологии: от криминальных практик к социальному институту // Митна справа. - 2010. - №6(72). 
25. Зардания Д.А. Политическая коррупция как форма теневой власти: Автореф. дисс. .... кандид. полит. наук. - Ростов-на-Дону, 2012.

26. Ильин О.С. Некоторые аспекты состояния организованной преступности в политической сфере жизни общества // Организованный терроризм и организованная преступность. - М.: Российская криминологическая ассоциация, 2002.

27. Кабанов П.А. Криминальная конспирология: понятие и предмет // Криминологический журнал Байкальского государственного университета экономики и права. - 2008. - №3.

28. Кабанов П.А. Криминологическая таксономия: понятие, содержание, таксономические единицы и основания их группировки // Криминологический журнал Байкальского государственного университета экономики и права. - 2007. - №1-2.

29. Кабанов П.А. Политическая криминология новое научное направление в отечественной криминологии (ее предмет и система) // Следователь. - 1999. - №1.

30. Кабанов П.А. Политическая преступность: понятие, сущность, виды, причины, личность политического преступника, меры противодействия (криминологическое исследование): Дисс. ... доктора юрид. наук. - Казань, 2008.

31. Каутский К. Генезис политических преступлений // Проблемы марксизма. Сборник второй: Проблемы преступности / Под ред. и с предисловием Я.С. Розанова. - Киев, 1924.

32. Каутский К. Природа политический преступлений. - Киев: Типография Ф.А. Борисова, 1905.

33. Квон Д.А. Политическая преступность: проблема концептуализации и актуальные практики: Автореф. дисс. ... кандид. полит. наук. - М., 2008 .

34. Кнительшот О.В. Система противодействия политическому экстремизму в современном обществе: Автореф. дисс. ... кандид. социолог. наук. - Саратов, 2006.

35. Косякова М.Е. Правовая превенция политического экстремизма: институциально-технологический аспект: Автореф. дисс. ... кандид. юрид. наук. Ростов-на-Дону, 2008.

36. Кудрина Н.Н. Политический терроризм: сущность, формы проявления, меры противодействия: Дисс. ... кандид. полит. наук. - СПб., 2000.

37. Кулаков А.Ф. Политическая преступность: криминологический и правовой аспекты: Дисс. ... кандид. юрид. наук. - Рязань, 2002.

38. Лабунец М.И. Политический экстремизм: этоннациональная регионализация: Дисс. ... кандид. полит. наук. - Ростов-на-Дону, 2002.
39. Ломброзо Ч., Ляски Р. Политическая преступность и революция по отношению к праву, уголовной антропологии и государственной науке/ Предисловие проф. А.И. Исаева. - СПб., 2003.

40. Лунеев В.В. Курс мировой и российской криминологии. В 2 т. Т.II. Особенная часть. - М., 2011.

41. Мороз Р.И. Терроризм как форма политического экстремизма: тенденции развития в 1990-2004 гг.: Дисс. ... кандид. полит. наук. - М., 2004.

42. Номоконов В.А. Современная криминология: традиционные подходы и новые направления // Организованная преступность, миграция, политика / Под ред. проф. А.И. Долговой. - М.: Российская криминологическая ассоциация, 2002.

43. Оболонский А.В. Геополитика - аморальный вид ложного сознания и цивилизационные альтернативы // Политическая концептология. - 2010. - №1. - С.54.

44. Сазонов И.А. Природа и исторические формы политического экстремизма. На примере политического развития России в XX веке: Дисс. ... кандид. полит. наук. - М., 2004.

45. Семынин А.С. Противодействие политической коррупции политико-правовыми средствами в государствах Евросоюза (опыт Финляндии и Эстонии): Автореф. дисс. ... кандид. политолог. наук. - Казань, 2009.

46. Старков О.В. Истоки новых направлений в криминологии // Закономерности преступности, стратегия борьбы и закон / Под ред. проф. А.И. Долговой. - М.: Российская криминологическая ассоциация, 2001.

47. Устинов В.С. Отечественная криминология ХХ века // Вестник Нижегородского университета им. Н.И. Лобачевского. Серия Право. Выпуск 2 (4). Государство и право: итоги ХХ века. - Н. Новгород: Изд-во ННГУ, 2001.

48. Шестаков Д.А. Введение в криминологию закона. - СПб.: Изд-во «Юридический центр пресс», 2011.

49. Шестаков Д.А. Криминология. Преступность как свойство общества: Краткий курс. - СПб.: Изд-во «Лань», 2001.

50. Янгол В.Н. Оперативно-розыскное противодействие политическому терроризму: Дисс. ... кандид. юрид. наук. - СПб., 2006.

\section{References (transliteration):}

1. Carlen P. Jigsaw: a political criminology of youth homeless ness. - Vinton Keynes: Open University press, 1996.

2. Elisaberg V. Linguistics and Political Criminology // Journal of Criminal Psychology. - 1944. - №5. 


\section{Право и политика 7 (163) • 2013}

3. Eskridge Ch.W. The State of the Field of Criminology // Journal of Contemporaru Criminal Justice. - 2005. - Vol.21. - №4.

4. Markantonatou M. The Modernisation Process of Official Social Control: Transformations of Social Control in the Frame of Neoliberalism, Aspects of Political Criminology. - Max Planck Society, 2005.

5. Scheingold S. A. Constructing the New Political Criminology: Power, Authority, and the Post-Liberal State // Law and Social inquiry. - 1998. - №1.

6. Aleksandrova N.S., Burlakov V.N., Shestakov D.A. Problemy ekonomicheskoy kriminologii // Pravovedenie. - 1998. - №1.

7. Antonov O.Yu. Teoriya i praktika vyyavleniya i rassledovaniya elektoral'nyh prestupleniy: Avtoref. diss. ... d-ra yurid. nauk. - M., 2008.

8. Astanin V.V. Reagirovanie na proyavleniya organizovannoy prestupnoy deyatel'nosti v sfere izbiratel'nyh processov // Reagirovanie na prestupnost': koncepcii, zakon, praktika. - M.: Rossiyskaya kriminologicheskaya associaciya, 2002.

9. Bashkirov N.V. Mery administrativno-pravovogo protivodeystviya politicheskomu ekstremizmu: Diss. .. kandid. yurid. nauk. - M., 2005.

10. Botalova D.B. Suschnost', osobennosti i faktory politicheskoy korrupcii kak neformal'nogo instituta v usloviyah sistemnoy transformacii rossiyskogo obschestva: Diss. ... kandid. polit. nauk. - SPb., 2011.

11. Voronov I.V. Osnovy politiko-pravovogo ogranicheniya social'no-politicheskogo ekstremizma kak ugrozy nacional'noy bezopasnosti Rossiyskoy Federacii: Diss. kandid. polit. nauk. - M., 2003.

12. Vorotnikov V.P. Tenevizaciya obschestva: osobennosti rossiyskogo politicheskogo processa // Vestnik Rossiyskogo universiteta druzhby narodov. - Seriya: Politologiya. - 2004. - №1(5).

13. Gilinskiy Ya.I. Deviantologiya: sociologiya prestupnosti, narkotizma, prostitucii, samoubiystv i drugih «otkloneniy». 2-e izd., ispr. i dop. - SPb., 2007.

14. Gilinskiy Ya.I. Kriminologiya: teoriya, istoriya, empiricheskaya baza, social'nyy kontrol'. 2-e izd., pererab. i dop. - SPb., 2009.

15. Gorshenkov A.G., Gorshenkov G.G., Gorshenkov G.N. Prestupnost' kak element politicheskoy sistemy // Vestnik nauchnyh trudov Nizhnekamskogo filiala Moskovskogo gumanitarno-ekonomicheskogo instituta. Vyp.3. Chast' 2: Voprosy bor'by s prestupnost'yu. - Nizhnekamsk, 2001.

16. Gorshenkov G.N. Politicheskiy rezhim, sredstva massovoy informacii i prestupnost' // Politicheskiy rezhim i prestupnost' / Pod red. V.N. Burlakova, Yu.N. Volkova, V.P. Sal'nikova. - SPb., 2001.

17. Gorshenkov G.N. Kriminologicheskiy slovar'. N. Novgorod, 2007.
18. Grosse F. K voprosu o prirode politicheskih prestupleniy // Problemy marksizma. Sbornik vtoroy: Problemy prestupnosti / Pod red. i s predisloviem Ya.S. Rozanova. - Kiev, 1924.

19. Gruzdeva A.P. O meste prestupleniy, sovershaemyh v usloviyah izbiratel'nogo processa v sisteme otechestvennoy kriminologii // Aktual'nye voprosy ekonomiki i prava v sovremennoy Rossii: Sbornik nauchnyh trudov. Vyp.3. - Nizhnekamsk: Nizhnekamskiy filial MGEI, 1999.

20. Danilov A.P. Ubiystva po politicheskim motivam v sovremennoy Rossii (kriminologicheskiy i ugolovnopravovoy aspekty): Diss. ... kandid. yurid. nauk. - SPb., 2008.

21. Dikaev S.U. Recenziya na knigu: Shestakov D.A. Kriminologiya. Prestupnost' kak svoystvo obschestva: Kratkiy kurs. - SPb.: Izd-vo «Lan'», 2001. - 260 s. // Preduprezhdenie prestupnosti. - 2002. - №1.

22. Dolgova A.I. Teoreticheskie problemy kriminologii kak nauki // Preduprezhdenie prestupnosti. - 2001. - №1.

23. Dolgova A.I., Astanin V.V., Dzyuba D.I. i dr. Deyatel'nost' organizovannoy prestupnosti v politicheskoy sfere zhizni obschestva // Organizovannaya prestupnost', migraciya, politika / Pod red. A.I. Dolgovoy. - M.: Rossiyskaya kriminologicheskaya associaciya, 2002.

24. Dremin V.N. K voprosu o predmete institucional'noy kriminologii: ot kriminal'nyh praktik k social'nomu institutu // Mitna sprava. - 2010. - №6(72).

25. Zardaniya D.A. Politicheskaya korrupciya kak forma tenevoy vlasti: Avtoref. diss. .... kandid. polit. nauk. - Rostov-na-Donu, 2012.

26. Il'in O.S. Nekotorye aspekty sostoyaniya organizovannoy prestupnosti $\mathrm{v}$ politicheskoy sfere zhizni obschestva // Organizovannyy terrorizm i organizovannaya prestupnost'. - M.: Rossiyskaya kriminologicheskaya associaciya, 2002.

27. Kabanov P.A. Kriminal'naya konspirologiya: ponyatie i predmet // Kriminologicheskiy zhurnal Baykal'skogo gosudarstvennogo universiteta ekonomiki i prava. 2008. - №3.

28. Kabanov P.A. Kriminologicheskaya taksonomiya: ponyatie, soderzhanie, taksonomicheskie edinicy i osnovaniya ih gruppirovki // Kriminologicheskiy zhurnal Baykal'skogo gosudarstvennogo universiteta ekonomiki i prava. - 2007. - №1-2.

29. Kabanov P.A. Politicheskaya kriminologiya - novoe nauchnoe napravlenie $\mathrm{v}$ otechestvennoy kriminologii (ee predmet i sistema) // Sledovatel'. - 1999. - №1.

30. Kabanov P.A. Politicheskaya prestupnost': ponyatie, suschnost', vidy, prichiny, lichnost' politicheskogo prestupnika, mery protivodeystviya (krimino- 
DOI: $10.7256 / 1811-9018.2013 .7 .6986$

При цитировании этой статьи сноска на doi обязательна

Теория

logicheskoe issledovanie): Diss. ... doktora yurid. nauk. - Kazan', 2008.

31. Kautskiy K. Genezis politicheskih prestupleniy // Problemy marksizma. Sbornik vtoroy: Problemy prestupnosti / Pod red. i s predisloviem Ya.S. Rozanova. - Kiev, 1924.

32. Kautskiy K. Priroda politicheskiy prestupleniy. Kiev: Tipografiya F.A. Borisova, 1905.

33. Kvon D.A. Politicheskaya prestupnost': problema konceptualizacii i aktual'nye praktiki: Avtoref. diss. ... kandid. polit. nauk. - M., 2008.

34. Knitel'shot O.V. Sistema protivodeystviya politicheskomu ekstremizmu v sovremennom obschestve: Avtoref. diss. ... kandid. sociolog. nauk. - Saratov, 2006.

35. Kosyakova M.E. Pravovaya prevenciya politicheskogo ekstremizma: institucial'no-tehnologicheskiy aspekt: Avtoref. diss. ... kandid. yurid. nauk. - Rostov-naDonu, 2008.

36. Kudrina N.N. Politicheskiy terrorizm: suschnost', formy proyavleniya, mery protivodeystviya: Diss. ... kandid. polit. nauk. - SPb., 2000.

37. Kulakov A.F. Politicheskaya prestupnost': kriminologicheskiy i pravovoy aspekty: Diss. ... kandid. yurid. nauk. - Ryazan', 2002.

38. Labunec M.I. Politicheskiy ekstremizm: etonnacional'naya regionalizaciya: Diss. ... kandid. polit. nauk. - Rostov-na-Donu, 2002.

39. Lombrozo Ch., Lyaski R. Politicheskaya prestupnost' i revolyuciya po otnosheniyu $\mathrm{k}$ pravu, ugolovnoy antropologii i gosudarstvennoy nauke/ Predislovie prof. A.I. Isaeva. - SPb., 2003.

40. Luneev V.V. Kurs mirovoy i rossiyskoy kriminologii. V 2 t. T.II. Osobennaya chast'. - M., 2011.
41. Moroz R.I. Terrorizm kak forma politicheskogo ekstremizma: tendencii razvitiya v 1990-2004 gg.: Diss. ... kandid. polit. nauk. - M., 2004.

42. Nomokonov V.A. Sovremennaya kriminologiya: tradicionnye podhody i novye napravleniya // Organizovannaya prestupnost', migraciya, politika / Pod red. prof. A.I. Dolgovoy. - M.: Rossiyskaya kriminologicheskaya associaciya, 2002.

43. Obolonskiy A.V. Geopolitika - amoral'nyy vid lozhnogo soznaniya i civilizacionnye al'ternativy // Politicheskaya konceptologiya. - 2010. - №1. - S.54.

44. Sazonov I.A. Priroda i istoricheskie formy politicheskogo ekstremizma. Na primere politicheskogo razvitiya Rossii v HH veke: Diss. ... kandid. polit. nauk. - M., 2004.

45. Semynin A.S. Protivodeystvie politicheskoy korrupcii politiko-pravovymi sredstvami v gosudarstvah Evrosoyuza (opyt Finlyandii i Estonii): Avtoref. diss. ... kandid. politolog. nauk. - Kazan', 2009.

46. Starkov O.V. Istoki novyh napravleniy v kriminologii // Zakonomernosti prestupnosti, strategiya bor'by i zakon / Pod red. prof. A.I. Dolgovoy. - M.: Rossiyskaya kriminologicheskaya associaciya, 2001.

47. Ustinov V.S. Otechestvennaya kriminologiya $\mathrm{HH}$ veka // Vestnik Nizhegorodskogo universiteta im. N.I. Lobachevskogo. Seriya Pravo. Vypusk 2 (4). Gosudarstvo i pravo: itogi HH veka. - N. Novgorod: Izd-vo NNGU, 2001.

48. Shestakov D.A. Vvedenie v kriminologiyu zakona. SPb.: Izd-vo «Yuridicheskiy centr press», 2011.

49. Shestakov D.A. Kriminologiya. Prestupnost' kak svoystvo obschestva: Kratkiy kurs. - SPb.: Izd-vo «Lan'», 2001.

50. Yangol V.N. Operativno-rozysknoe protivodeystvie politicheskomu terrorizmu: Diss. ... kandid. yurid. nauk. - SPb., 2006. 